\title{
Civil law regulation of investments in the digital infrastructure of the construction industry
}

\author{
Anna Pugacheva ${ }^{1}$, Marseille Hakimullin ${ }^{2}$, Marat Badrutdinov*20000-0001-7939-9429], Svetlana Kashina ${ }^{2}$, \\ and Aleksandr Lunev ${ }^{3}$ \\ ${ }^{1}$ Kazan (Volga region) Federal University, 420014 Kazan, Russia \\ ${ }^{2}$ Kazan State University of Architecture and Engineering, 420043 Kazan, Russia \\ ${ }^{3}$ Kazan National Research Technical University named after Tupolev-KAI, 420111 Kazan, Russia
}

\begin{abstract}
Civil law regulation of investments combines regulations from different industry sectors and is characterized by its complexity. An efficient type of investment in the digital infrastructure of the construction industry is a financial lease. The purpose of the study is to characterize the civil law regulation of a financial lease. The methodological basis was the technical and legal method that ensures the effectiveness of the analysis of civil law regulation of a financial lease, the adequacy of the assessment of concepts and legal structures. The following results of the study have been obtained: the content of the international financial leasing transaction and the essence of a financial lease in Russia have been determined; particular aspects of the implementation of the UNIDROIT Convention in Russia have been identified. The content of the international financial leasing transaction reflects a threeway process with the participation of the equipment seller, lessor and lessee, who are linked by a supply contract and a lease contract. In Russian legislation, the term «financial lease» is used. The essence of a financial lease reflects both a lease contract with elements of sale in conjunction with the purchase option and the type of secured financing. Particular aspects of the implementation of the UNIDROIT Convention in Russia are due to different terminology and are associated with cross-border leasing. A draft federal law is undergoing a regulatory impact assessment, which provides for the introduction of a financial lease concept. Civil law regulation of leasing relations will ensure the effectiveness of attracting investments in order to improve the digital infrastructure of the construction industry.
\end{abstract}

Keywords. Civil law regulation of investments, lease, digital infrastructure, digital construction.

\section{Introduction}

Civil law regulation of investments is characterized by a set of principles, methods, forms and means of law making, law exercising and law enforcement activity [1]. A particular feature of the civil law regulation of investments is that it combines the regulations of

${ }^{*}$ Corresponding author: badrutdinovm@gmail.com 
different industry affiliations (constitutional, civil, criminal and administrative) and is characterized by its complexity [2].

A complex attribute of civil law regulation of investments includes multisectoral coordination in order to eliminate contradictions and to harmonize legal rules in the course of law enforcement practice [3]. For example, the efficiency of investments attraction in order to improve the digital infrastructure of the construction industry will increase if the inconsistency of regulations adopted at various times, at different levels and by different standard-setting organizations is eliminated. Adoption of comprehensive regulations is intended in order to achieve multisectoral coordination. Comprehensive legal acts ensure the coordination of the different industries regulations in relation to investment activities on the basis of centralized and dispositive regulation [4].

The improvement of the construction industry digital infrastructure is the part of the strategic development objectives of the Russian Federation [5]. Digital infrastructure is considered as a modern support tool of digital transformation in the construction industry. Target results are as follows: establishment of a unified standard for the construction industry digitalization; management of the optimal technical solutions choice and construction time reduction; improvement of the budget planning accuracy and costs reduction. A federal project «Digital Construction» has been developed in order to achieve the target results. The project provides for the introduction of modern IT solutions of cloud services for building information modeling (BIM) at all stages of capital construction of an object; project management in the field of civil and industrial construction; management of the electronic fund of regulatory and technical documents, electronic library of information models of multiple use; establishment of the electronic base of building materials, equipment and their prices; ensuring the workplace safety. Examples of BIM models in Russia can be «Arena» multifunctional sports centers in the cities of Moscow, Kazan and Saransk, the «Lakhta Center» business center in the city of St. Petersburg. The improvement of the construction industry digital infrastructure requires investments with long payback periods and high capital intensity. This made the development of civil law regulation of investments in the digital infrastructure of the construction industry relevant.

The object of study is the civil law regulation of investments in the digital infrastructure of the construction industry. The essence of civil law regulation is to streamline the content of legal rules to increase investor loyalty to the digital infrastructure of the construction industry, to protect their rights and legitimate interests, to provide freedom of choice of investment object to the investor, to ensure the mutually beneficial combination of the state and investors interests. An effective type of investment in the digital infrastructure of the construction industry is financial lease [6]. A finance lease combines the elements of lease, credit and investment operations. Civil law regulation of a financial lease ensures the implementation of IT technologies in the construction process, improvement of contractor's digital assets state [7]. The purpose of the study is to characterize the civil law regulation of a financial lease.

\section{Methods}

The methodological basis of the study was the technical and legal method that ensures the effectiveness of the analysis of civil law regulation of a financial lease, the adequacy of the assessment of concepts and legal structures.

analysis of special literature), as well as the method of interpreting law, technical and comparative legal methods. The legal basis for the study were:

- UNIDROIT Convention on International Financial Leasing [8]; Federal'nyi zakon «O prisoedinenii Rossiiskoi Federatsii k Konventsii UNIDRUA o mezhdunarodnom finansovom lizinge» of 16 yanvarya 1998 g. [The Federal Law «On the Accession of the Russian 
Federation to the UNIDROIT Convention on International Financial Leasing» of January 16, 1998. (In Russ.)] [9];

- Grazhdanskij Kodeks Rossijskoj Federacii (chast' pervaja) ot 30.10.1994 № 51-FZ [The Civil Code Of The Russian Federation Part One No. 51-FZ of November 30, 1994] [10]; Grazhdanskij Kodeks Rossijskoj Federacii (chast' vtoraja) ot 26.01.1996 № 14-FZ [The Civil Code Of The Russian Federation Part Two No. 14-FZ of January 26, 1996] [11];

- Federal'nyj zakon RF «O finansovoj arende (lizinge)» ot 29.10.1998 №164-FZ [Federal Law of the Russian Federation «On the Financial Lease» of October 29, 1998 No. 164-FZ] [12];

- Code des juridictions financières [13]; Code civil [14].

\section{Results}

The following results of the study have been obtained: the content of the international financial leasing transaction and the essence of a financial lease in Russia have been determined; particular aspects of the implementation of the UNIDROIT Convention in Russia have been identified.

\subsection{The content of the international financial leasing transaction}

The content of the international financial leasing transaction is revealed in the UNIDROIT Convention on International Financial Leasing (Ottawa, 28 May 1988). The UNIDROIT Convention defines lease as a single three way transaction that involves the seller of the equipment, the lessor and the lessee, who are linked by a supply contract and a lease contract. The concept of financial leasing transaction is given in the first article of the Convention. The nature of the transaction is that one party (lessor) makes a supply contract with a third party (supplier) according to the specification of the other party (lessee). The lessor, on the terms approved by the lessee to the extent that they affect their interests, purchases equipment and makes a lease contract with the lessee. The lease contract provides the lessee with the right to use the equipment on the basis of recurring payments. The UNIDROIT Convention is applied regardless of the lessee's right to buy the equipment (or acquire such a right afterwards) or to continue to use it under the terms of a lease contract thereafter, as well as regardless of the nominal price payment or recurring payments. The Convention does not mention the possibility of the lessee to acquire the object of the lease contract ahead of schedule at the end of the term of this contract.

Today, the role of international financial lease, in which the seller of equipment, the lessor and the lessee are located in different countries, is being increased [15]. The practice of using digital equipment, platform solutions and software on leasing terms has already become widespread. Digital startups are becoming increasingly popular [16]. The construction industry is already a consumer of developed digital technologies [17]. The value of an international financial leasing transaction for the construction industry is obvious: digital technologies are developing very quickly and it's effective to e digital assets through leasing [18].

\subsection{The essence of a financial lease in Russia}

There is no concept of «financial lease» in Russian legislation. There is a federal act «About financial lease» in Russia that is aimed at the development of various types of investment activities. The act defines lease as economic and legal relations that arise in the course of the lease contract implementation. The essence of the «financial lease» concept is not determined in the law. This led to the establishment of two models of a financial lease: rental and financial. 
The rental model was based on the provisions of the UNIDROIT Convention [19]. A financial lease is considered as a type of the lease contract with the elements of sale in conjunction with the possibility of the right to purchase. The essence of a financial lease is as follows: the lessor acquires the equipment in its ownership and transfers it into the possession and use of the lessee on the condition of recurrent lease payments. These lease payments make up the lessor's revenue from investment activities [20].

A financial lease includes three contracts.

Firstly, there is a sales contract between the lessor and the seller of the equipment. The essence of this contract is determined by the current civil legislation.

Secondly, it includes a financial lease contract between the lessor and the lessee. The financial lease contract defines a complex of legal and economic relations. The essence of this contract is the lessor's obligation to acquire the ownership of the equipment specified by the lessee from the seller specified by him and to provide the lessee with this equipment for temporary possession and use for a fee. The essence of this contract allows to highlight several components in leasing legal relations: 1) lease (transfer of equipment into possession and use);2) purchase and sale by installments (transfer of equipment after payment of all lease payments); 3) credit (there is an interest and principal debt); 4) order (the lessee instructs the lessor to purchase certain equipment from a specific seller).

Thirdly, a financial lease includes a contract of sale between the lessor and the lessee for the purchase of equipment. The essence of this contract determines the procedure for the purchase of equipment if the financial lease contract does not include the equipment transfer after all lease payments have been paid. Unfortunately, the procedure for accounting for the purchase price of equipment is not enshrined in the current Russian legislation. Compensation of the lessor's costs associated with the purchase and transfer of equipment to the lessee and the lessor's revenue are included in lease payments. If the financial lease contract includes the transfer of ownership of the equipment from the lessor to the lessee, then the purchase price is not included in the lease payments. The purchase price of the leased equipment is considered as an expense for the acquisition of depreciable property according to article 270 of the Tax Code. The lessee should consider the cost of lease payments and the cost of buying out depreciated (leased) property separately.

Proponents of the financial model interpret a financial lease as the transfer of money hidden in the equipment to the borrower. This interpretation is based on the theory of balance: there is a final (compensational) payment upon termination of a financial lease contract in conditions of incomplete lease payments. The final payment can be made both in favor of the lessor (for the return of the loan and agreed interest for the actual time of its use) and the lessee [21].

The essence of a financial lease reflects a mixed contract that combines the features of doing someone else's business and a loan. The lender invests money in the equipment specified by the borrower (acquires it) and transfers it to the borrower along with the equipment (inside it). The lessor's interest lies in the placement and subsequent return with a profit of money. Acquisition of the leased asset ownership serves the lessor as a security for the lessee's obligations to pay the payments established by the contract, as well as a guarantee of return on investment. A financial lease is defined as a type of secured financing [22]. The lessor acquires ownership of the leased equipment to secure the lessee's monetary obligation to return the financing provided to them.

\subsection{Particular aspects of the implementation of the UNIDROIT Convention in Russia}

Particular aspects of the implementation of the UNIDROIT Convention in Russia are due to differences in terminology [23]. The UNIDROIT Convention uses the concept of «finance 
leasing transaction». In Russian legislation, the concept of «financial leasing contract» is used. Russia has ratified the UNIDROIT Convention by Federal Law No. 16-FZ of 08.02.1998 «On the Accession of the Russian Federation to the UNIDROIT Convention on International Financial Leasing». Article 8 of the UNIDROIT Convention is not applied in Russia according to this law. This article allows including a condition on the possibility to release the lessor from any liability to the lessee in the leasing contract. The content of the Article 8 of the UNIDROIT Convention contradicts paragraph 4 of Article 401 of the Russian Federation Civil Code (an agreement that is concluded in advance on the elimination or limitation of liability for willful violation of obligation is considered to be insignificant).

In Russia, the UNIDROIT Convention is applied under the following circumstances: the commercial enterprises of the lessor and the lessee are located in different states; these states, as well as the state in which the seller has their own place of business, parties to the UNIDROIT Convention or the supply contract and leasing contract are governed by the national law of one of the member states of the Convention. The application of the UNIDROIT Convention provisions may be excluded with the mutual consent of the subjects of the purchase and sale contract or leasing contract.

A draft federal law on amendments to the Civil Code of the Russian Federation has been developed to improve the civil law regulation of leasing [24]. The draft provides for the introduction of the financial leasing concept. The following methods of civil legal regulation of financial leasing are proposed: establishing the features of a financial leasing contract that meets the requirements of integrity, consistency and certainty; minimizing the risks due to transparency and consistency of legal regulations; ensuring a balance of interests of the subjects, by protecting the rights of the lessee and the property interests of the lessor. The draft is undergoing a regulatory impact assessment and provides for the granting of an independent qualification to the financial lease contract.

\section{Discussions}

The use of leasing as an effective type of investment is hampered by the inconsistency between legal standards and law enforcement practice, national and international standards.

The rental model of a financial lease is based on the current legal standards. The essence of the rental model of a financial lease is that the ownership of the leased equipment remains with the lessor for the entire period of the contract; the lessee cannot buy the equipment during the term of the contract; lease payments are recognized as current expenses for a particular financial period. This point of view on the essence of a financial lease allows the improvement of the rental model of the lease, in which leased equipment is required for a short-term period, or the obsolescence of the equipment is ahead of the physical deterioration. For the development of the digital infrastructure of the construction industry, the rental model will be effective and will allow the implementation of information modeling technologies at all stages of the construction project [25].

The financial model of a financial lease is based on law enforcement practice. The financial model of a financial lease reflects the method of financing, which provides for the ownership transfer of the leased equipment from the lessor to the lessee at the end of the contract. The lessee can buy the equipment at the final stage of the contract. Lease payments are recognized as property, plant and equipment. This point of view on the essence of a financial lease allows the introduction of the financial «leasing concept». Leasing companies will be able to receive direct subsidies for the development of leasing as an independent investment instrument. Lessees will be able to acquire production assets if their own funds are insufficient. The financial model is effective for the development of the digital infrastructure of the construction industry as well and allows the establishment of digital assets [26]. 
The rental and financial models of a financial lease are interrelated and bring legal certainty to two types of leasing: leasing-renting and leasing-financing.

Inconsistency between national and international standards is due to different terminology. National legal standards use the concept of «finance lease contract». International legal standards (UNIDROIT Convention) use the concept of «finance lease transaction». The lack of unification of regulatory legal terminology distorts the interests of the lessor and the lessee, creates difficulties in the process of building leasing relations [27].

\section{Conclusion}

In Russian legislation, the current legal regulations classify leasing as a type of rent (rental model of leasing). Law enforcement practice considers leasing as a form of lending (financial leasing model): the lender invests money in the equipment specified by the borrower (acquires it) and transfers it to the borrower on the basis of recurring payments (transfer of money hidden in the equipment). Legal certainty of the concepts of «financial rent» and «financial lease» will ensure the effectiveness of attracting of investments to improve the digital infrastructure of the construction industry.

\section{References}

1. N.B. Cohen. Law Contemp. Probl. 81, (2018).

2. G.G. Castellano, M. Dubovec. Law Contemp. Probl. 81, (2018).

3. D.K. Tarullo, Law Contemp. Probl. 83, (2020).

4. E.V. Sapir, I.A. Karachev, Financ. Theory Pract. 24, (2020)

5. Ukaz Prezidenta RF «O natsional'nykh tselyakh i strategicheskikh zadachakh razvitiya Rossiyskoy Federatsii na period do 2024 goda» 2018 [Decree of the President of the Russian Federation «On national goals and strategic objectives of the development of the Russian Federation for the period until 2024» 2018]. Available at: http://publication.pravo.gov.ru/Document/View/0001201805070038 (Accessed: 14 march 2021).

6. E.V. Sapir, I.A. Karachev. Financ. Theory Pract. 24, (2020).

7. G. Gagliani. J. Int. Econ. Law 23, (2020).

8. UNIDROIT Convention on International Financial Leasing 1988 Availalbe at: https://www.unidroit.org/leasing-ol/leasing-english (Accessed: 14 march 2021)

9. Federal'nyi zakon «O prisoedinenii Rossiiskoi Federatsii k Konventsii UNIDRUA o mezhdunarodnom finansovom lizinge» 1998 [The Federal Law «On the Accession of the Russian Federation to the UNIDROIT Convention on International Financial Leasing» 1998] Available at: http://base.garant.ru/177620/ (Accessed: 14 march 2021)

10. Grazhdanskij Kodeks Rossijskoj Federacii (chast' pervaja) 1994 [The Civil Code Of The Russian Federation Part One 1994]. Available at: http://base.garant.ru/10164072/\# friends (Accessed: 14 march 2021).

11. Grazhdanskij Kodeks Rossijskoj Federacii (chast' vtoraja) 1996 [The Civil Code Of The Russian Federation Part Two 1996]. Available at: http://base.garant.ru/10164072/\# friends (Accessed: 14 march 2021).

12. Federal'nyj zakon RF «O finansovoj arende (lizinge)» 1998 [Federal Law of the Russian Federation «On the Financial Lease» 1998] Available at: http://base.garant.ru/ 12113492/ (Accessed: 14 march 2021).

13. Code des juridictions financières. Dernière mise à jour des données de ce code 2020 Available at: https://www.legifrance.gouv.fr/liste/circ (Accessed: 14 march 2021). 
14. Code civil, 21 March, 1804. Dernière mise à jour des données de ce code 2020. Available at: https://www.legifrance.gouv.fr/liste/circ (Accessed: 14 march 2021).

15. S.R. Goode. Law Contemp. Probl. 81, (2018).

16. M. Deloof, T. Vanacker, J. Bus. Financ. Account. 45, (2018).

17. N. Pugacheva, M. Badrutdinov, S. Kashina, L. Yarullina, R. Farah, T. Kirillova, A. Lunev. IOP Conf. Ser. Mater. Sci. Eng. (2020).

18. A. Khuzin, R. Ibragimov, J. Build. Eng. 35, 102030 (2021).

19. M.P. Afanas'ev, N. N. Shash. Stud. Russ. Econ. Dev. 31, (2020).

20. I. Lifshits, V. Ponamorenko. Russ. Law J. 8, (2020).

21. R. Kasyanov, A. Kriger. Russ. Law J. 8, (2020).

22. E. Ryabova. Russ. Law J. 7, (2019).

23. B. Rebrysh, N. Maskayeva. Russ. Law J. 7, (2019).

24. Proyekt Federal'nogo zakona «O vnesenii izmeneniy v chasti pervuyu, vtoruyu i tret'yu Grazhdanskogo kodeksa Rossiyskoy Federatsii (v chasti sovershenstvovaniya grazhdansko-pravovogo regulirovaniya lizingovoy deyatel'nosti)» 2018 [Draft Federal Law «On Amendments to Parts One, Two and Three of the Civil Code of the Russian Federation (in terms of improving the civil law regulation of leasing activities)» 2018] Available at: http://www.doclist.ru/sitemap-7466.html (Accessed: 14 march 2021)

25. V.L. Badenko, N.S. Bolshakov, E.B. Tishchenko, A.A. Fedotov, A.C. Celani, V.K. Yadykin. Mag. of Civil Eng. 101, (2020).

26. R.A. Ibragimov, E.V. Korolev, T.R. Deberdeev, V.V. Leksin. Struct. Concr. 20, (2019).

27. B.N. Porfiryev, A.A. Shirov, M.N. Uzyakov, M.S. Gusev, I.N. Shokin. Stud. Russ. Econ. Dev. 31, (2020). 